\title{
Implementasi Media Pembelajaran E-Learning Berbasis Web Materi Elastisitas dan Hukum Hooke untuk Meningkatkan Prestasi Belajar Siswa SMK Negeri 1 Sambirejo
}

\author{
Ratih Saputri R.W ${ }^{1)}$, Tantri Mayasari' ${ }^{2)}$, Farida Huriawati ${ }^{3)}$ \\ ${ }^{1)}$ Mahasiswa Prodi Pendidikan Fisika.UNIVERSITAS PGRI MADIUN \\ ${ }^{2)}$ Dosen Pendidikan Fisika.UNIVERSITAS PGRI MADIUN \\ ${ }^{3)}$ Dosen Pendidikan Fisika.UNIVERSITAS PGRI MADIUN \\ email: ratih_saputri@yahoo.com; bu_tantri@yahoo.com; frd21pfisae@gmail.com
}

\begin{abstract}
The purpose of this research is to improve student's learning achievement with web-based ELearning media in grade X students of SMK Negeri 1 Sambirejo Sragen. This research is in the form of Classroom Action Research (PTK) with satusiklus. Each cycle includes the planning, implementation, observation, and reflection phases. The subject of this research is the students of class X SMK Negeri 1 Sambirejo Sragen semester of the academic year 2016/2017, with the number of students 32 students. Instrument of data collecting in this research is observation sheet, student response questionnaire sheet to learning, pre test pre test and post test to measure student achievement improvement. Sample selection technique in this research is cluster random sampling. The results showed the average value of student achievement improvement cycle 1 and cycle 2 which is expressed with the average $N$-Gain has increased with the acquisition in cycle 1 of 43.00 which is categorized and increased in cycle 2 of 72.56 are categorized being. As for the size of the impact or Effect Size in learning process shows the average value of student achievement increase from cycle 1 and cycle 2 to get the effect large 0.841 categorized effect. Based on the results of research conducted to prove that web-based E-Learning learning media can improve learning achievement as well as provide a great impact for students of class X SMK Negeri 1 Sambirejo Sragen. These findings provide new insight into the role of teachers and the different student control dimensions in ELearning with implications for learning processes and improved learning achievement. Given ELearning has been widely used in various kinds of other learning facilities, which is able to attract the attention of its users to be more innovative and creative.
\end{abstract}

Keywords: Academic Areas, E-Learning, Online Education, Data Management System, and SelfLearning

\begin{abstract}
Abstrak: Tujuan dari penelitian ini adalah untuk meningkatkan prestasi belajar siswa dengan media pembelajaran E-Learning berbasis web pada siswa kelas X SMK Negeri 1 Sambirejo Sragen. Penelitian ini berbentuk Penelitian Tindakan Kelas (PTK) dengan satusiklus. Setiap siklus mencakup tahap perencanaan, pelaksanaan, pengamatan, dan refleksi. Subyek penelitian ini adalah siswa kelas X SMK Negeri 1 Sambirejo Sragen semester genap tahun ajaran 2016/2017, dengan jumlah siswa 32 siswa. Instrumen pengumpulan data pada penelitian ini berupa lembar observasi, lembar angket respon siswa terhadap pembelajaran,tes pilihan ganda pre test dan post test untuk mengukur peningkatan prestasi belajar siswa. Teknik pemilihan sampel pada penelitian ini adalah cluster random sampling. Hasil penelitian menunjukkan nilai rata-rata peningkatan prestasi belajar siswa siklus 1 dan siklus 2 yang dinyatakan dengan rata-rata $N$-Gain mengalami peningkatan dengan perolehan pada siklus 1 sebesar 43,00yang dikategorikan sedang dan meningkat pada siklus 2 sebesar 72,56 yang dikategorikan sedang. Sedangkan untuk ukuran dampak atau Effect Sizedalam proses pembelajaran menunjukkan nilai rata-rata peningkatan prestasi belajar siswa dari siklus 1 dan siklus 2 memperoleh nilai Effect Size sebesar 0,841 yang dikategorikan besar. Berdasarkan hasil penelitian yang dilakukan
\end{abstract}


membuktikan bahwa media pembelajaran E-Learning berbasis web dapat meningkatkan prestasi belajar sekaligus memberikan dampak yang besar bagi siswa kelas X SMK Negeri 1 Sambirejo Sragen. Temuan ini memberikan wawasan baru tentang peran guru dan dimensi kontrol pelajar yang berbeda dalam E-Learning dengan implikasi untuk proses pembelajaran dan peningkatan prestasi belajar. Mengingat E-Learning sudah banyak dimanfaatkan diberbagai macam fasilitas pembelajaran yang lain, yang mampu menarik perhatian penggunanya untuk lebih inovatif dan kreatif.

Kata Kunci : Bidang Akademik, E-Learning, Pendidikan Online, Sistem Manajemen Data, dan Pembelajaran Mandiri.

\section{PENDAHULUAN}

Dalam dunia pendidikan sekarang ini pendidik ataupun siswa dituntut agar mengerti dan paham akan Teknologi Informasi Komputer (TIK) pada tingkat Sekolah Menengah Kejuruan (SMK). Kemajuan teknologi memberikan pengaruh yang signifikan dalam kehidupan masyarakat Indonesia. Perubahan pola pikir dan gaya hidup merupakan pengaruh dari perkembangan teknologi. Fakta banyak dijumpai penggunaan alat teknologi dalam melakukan berbagai aktivitas. Perubahan yang cepat dan pesat membuat Indonesia dikenal sebagai negara yang memiliki Sumber Daya Manusia (SDM) yang rendah. Dalam kenyataannya fasilitas sekolah SMK Negeri 1 Sambirejo pada kelas jurusan Teknologi Informatika yang memanfaatkan fasilitas 183ias183ato dan jaringan internet belum dimanfaatkan secara maksimal. Disisi lain tenaga pengajar sudah cukup berkompeten dalam bidangnya, akan tetapi kebanyakkan siswa belum mampu belajar banyak melalui fasilitas internet yang disediakan, siswa hanya mengandalkan buku cetak dari sekolahan.Proses pembelajaran Fisika masih bersifat kelas konvensional yaitu dengan metode ceramah, penggunaan media pembelajaran pun masih sangat minim terutama penggunaan media pembelajaran yang menggunakan fasilitas internet masih belum ada. Hasil belajar Fisika yang dicapai siswa kelas X rata-rata nilai sebesar 60,23 dari standar KKM 70,20. Temuan tersebut mengindikasikan bahwa upayaupaya yang dilakukan untuk meningkatkan kualitas pendidikan belum mencapai hasil maksimal.

Masih rendahnya prestasi belajar peserta didik tersebut merupakan indikator rendahnya mutu pendidikan. Oleh karena itu, perlu dianalisis secara cermat faktor-faktor penyebab rendahnya prestasi belajar peserta didik tersebut.Sejalan dengan hal tersebut diharapkan guru bisa membuat pembelajaran yang inovatif di setiap semesternya supaya guru lebih belajar lagi dan memahami konsep-konsep pembelajaran yang termotifasi oleh perangkat lunak yang disediakan komputer maupun internet supaya siswa tidak jenuh akan pembelajaran yang kontekstual dan konvensional saja. Maka dari itu SMK Negeri 1 Sambirejo Sragen mencanangkan program baru disemua bidang study. Saat ini E-Learning termasuk ke dalam program awal yang dicanangkan oleh pihak sekolah. E-Learning adalah sistem pendidikan yang menggunakan aplikasi elektronik untuk mendukung pengembangan kegiatan belajar mengajar dengan media internet atau media jaringan komputer lain. Dari uraian tersebut, mendorong penulis untuk mengadakan penelitian berjudul "Implementasi Media Pembelajaran E-Learning Berbasis Web Materi Elastisitas dan Hukum Hooke Untuk Meningkatkan Prestasi Belajar Siswa SMK Negeri 1 Sambirejo"

\section{METODE PENELITIAN}

Dalam penelitian ini, yang menjadi subyek penelitian adalah siswa kelas X SMK Negeri 1 Sambirejo Sragen tahun ajaran 2016/2017 yang terdiri dari 1 kelas berjumlah 32 siswa. Teknik pemilihan sampel pada penelitian ini adalah cluster random sampling. Penelitian yang 
digunakan adalah penelitian tindakan kelas (PTK) yang terdiri dari 2 siklus. Prosedur pelaksanaan penelitian dalam siklus 1 antara lain sebagai berikut :

A. Perencanaan

Peneliti terlebih dahulu menyusun perangkat pembelajaran yang akan digunakan nantinya antara lain RPP, Silabus, LKS dan soal pre test dan post testdengan materi elastisitas dan hokum hooke.

B. Pelaksanaan Tindakan

Siklus 1 dilaksanakan pada tanggal 1 Mei 2017 dengan proses pelaksanaan pembelajaran menggunakan media E-Learning berbasis web yang terdiri atas 5 tahap yaitu a) Orientasi: guru menjelaskan mengenai elastisitas kemudian siswa dibimbing untuk menjalankan media E-Learning menggunakan akun login masing-masing siswa kemudian siswa diarahkan untuk membuka menu materi pembelajaran yang ada di dalam media E-Learning dan mengamati setiap materi yang ditanyangkan agar nantinya siswa paham dan mengerti macam penerapan bahan elastisitas dalam kehidupan sehari-hari juga 184ias meng-upload materi sendiri sesuai dengan bidangnya masing-masing. B) Merumuskan Masalah : siswa merumuskan masalah berdasarkan fenomena yang diamati yaitu materi video pembelajaran yang diberikan. C) Merumuskan Hipotesis: siswa saling tukar pendapat dalam bentuk hipotesis terhadap rumusan masalah yang telah dibuat sebelumnya. D) Mengumpulkan Data: dengan melakukan observasi pada lingkungan sekolahan serta menganalisis materi disetiap video pembelajaran yang ada di dalam media E-Learning kemudian memberikan angket respon terhadap pembelajaran yang sudah disajikan. E) Menyimpulkan Hipotesis: Menyimpulkan hasil pembelajaran dari materi video pembelajaran yang sudah mereka lihat.

C. Pengamatan

Pada tahap pengamatan merupakan hasil dari pengamatan pelaksaan pembelajaran yang telah dilakukan, data hasil pre-test dan post-test materi elastisitas dan hukum hooke menggunakan media pembelajaran E-Learning berbasis web. Model pembelajaran dilakukan tes awal (pre-test) dan setelah implementasi model pembelajaran dilakukan tes akhir (post-test).

D. Refleksi

Pada kegiatan refleksi mengkaji kekurangan yang muncul pada siklus 1 . Ternyata pada siklus 1 belum mencapai target sehingga perlu dilakukan siklus 2 yang dilaksanakan pada tanggal 3 Mei 2017 yang terdiri atas 5 tahap yaitu: a) Orientasi: guru menjelaskan mengenai hokum hookekemudian siswa dibimbing untuk menjalankan media E-Learning menggunakan akun login masing-masing siswa, kemudian siswa diarahkan untuk membuka menu materi pembelajaran yang ada di dalam media E-Learning dan mengamati setiap materi yang ditanyangkan agar nantinya siswa paham dan mengerti macam penerapan hokum hooke dalam kehidupan sehari-hari juga bias meng-upload materi sendiri sesuai dengan bidangnya masing-masing. B) Merumuskan Masalah: siswa merumuskan masalah berdasarkan fenomena yang diamati yaitu materi video pembelajaran yang diberikan. C) Merumuskan Hipotesis: siswa saling tukar pendapat dalam bentuk hipotesis terhadap 
rumusan masalah yang telah dibuat sebelumnya. D) Mengumpulkan Data: dengan melakukan analisis materi disetiap video pembelajaran yang ada di dalam media $E$ Learning. E) Menguji Hipotesis: mengkomunikasikan analisis tersebut ke depan kelas dan mendiskusikannya secara bersama-sama.

Instrumen penelitian media pembelajaran E-Learning berbasis web materi elastisitas dan hokum hooke yang meliputi RPP, Silabus, LKS dan soal tes. Sumber data penelitian adalah hasil pre-test dan post-test yang berupa tes pilihan ganda yang meliputi empat fasilitator yaitu fluency, flexibility, originality, dan elaborasi yang diambil dari pre-test dan post test. Hasil pre-test dan post-test diolah dan dianalisis untuk mengetahui peningkatan prestasi belajar siswa. Untuk mengetahui peningkatan prestasi belajar antara sebelum dan sesudah pembelajaran dari setiap siklus diklasifikasikan berdasarkan penilaian nilai presentase gain ternormalisasi. Tinggi rendahnya skor gain yang dinormalisasi $(\mathrm{N}$-gain $)$ dapat diklasifikasikan dalam tiga kategori, yaitu: $N$-gain $>0,7$ kategori tinggi, $0,3 \leq N$-gain $\leq 0,7$ kategori sedang, $N$ gain $<0,3$ berkategori rendah.

\section{HASIL DAN PEMBAHASAN}

\subsection{HASIL PENELITIAN}

\section{1) Pelaksanaan}

Pada Siklus 1 siswa dibimbing untuk menjalankan media pembelajaran E-Learning berbasis web dengan cara login menggunakan NISN masing-masing siswa. Secara perlahan menuntun siswa menjalankan menu yang ada di dalam media E-Learning. Kemudian membuka menu materi pembelajaran yang berisikan video pembelajaran didalamnya. Setelah itu guru bersama murid melakukan diskusi kecil pada materi elastisitas. Dalam hal ini siswa juga mengerjakan soal pre-test pilihan ganda yang berada di dalam media E-Learning yang telah dibuka masing-masing siswa.

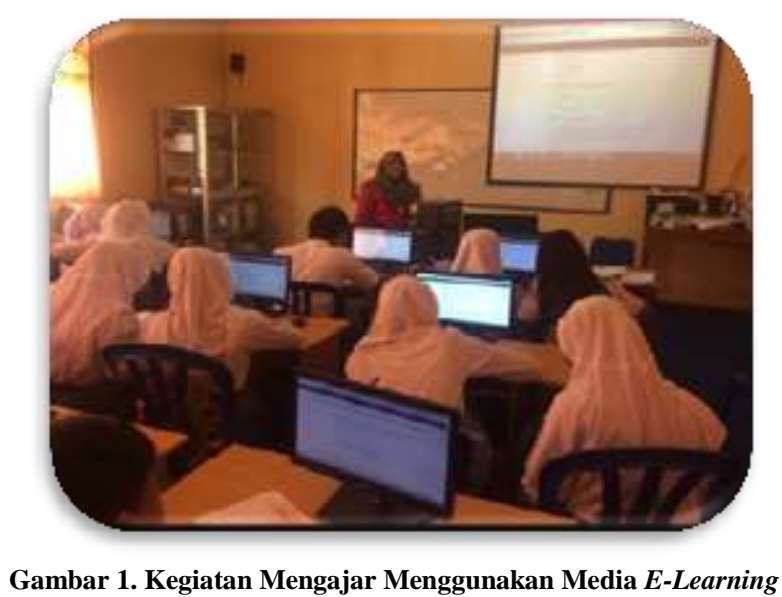

Berikut tampilan uji coba tes dengan menggunakan media E-Learning dan tampilan media pembelajaran E-Learning berupa video pembelajaran yang bisa diunduh dan di bagikan ke media lain. 


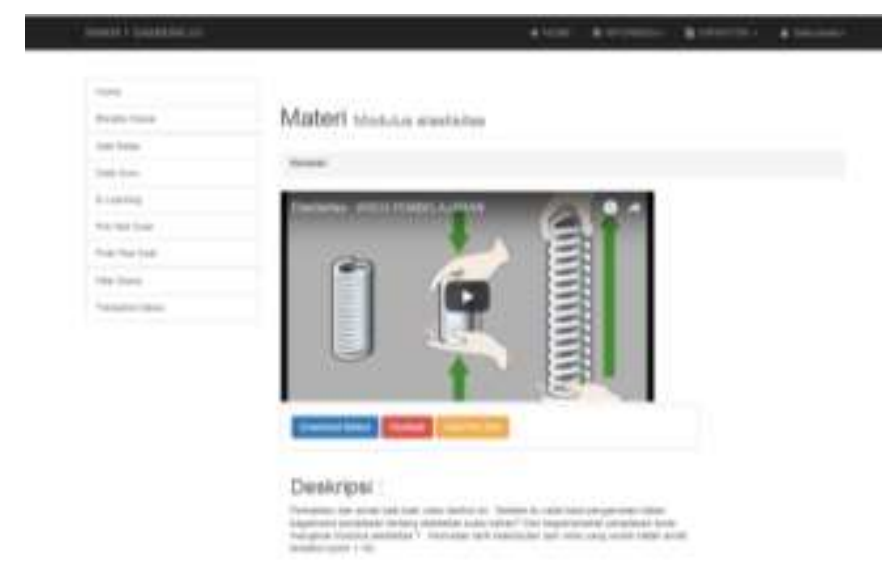

Gambar 2. Materi Pembelajaran Menggunakan Media E-Learning

Ketika membuka materi pembalajaran dalam media E-Learning pada tahap siklus I dan siklus II ini siswa diharapkan mampu merumuskan masalah berdasarkan fenomena yang diamati di dalam video pembelajaran yang ditampilkan. Serta siswa diharapkan mampu merumuskan hipotesis terhadap rumusan masalah yang telah dibuat. Sehingga siswa dapat menguji hipotesis dengan mengkomunikasikian analisis tersebut ke depan kelas dan mendiskusikan secara bersama-sama.

Setelah melakukan diskusi pada siklus I dan siklus II siswa diharapkan untuk mengerjakan soal pre-test pada siklus I dan soal post-test pada siklus II. Soal berupa pilihan ganda 10 butir soal dengan materi elastisitas dan hukum hooke pada kedua soal tersebut. Dalam hal ini siswa diharapkan mampu berpikir secara tepat dan cepat guna memaksimalkan waktu yang ada selama proses pembelajaran mengajar.

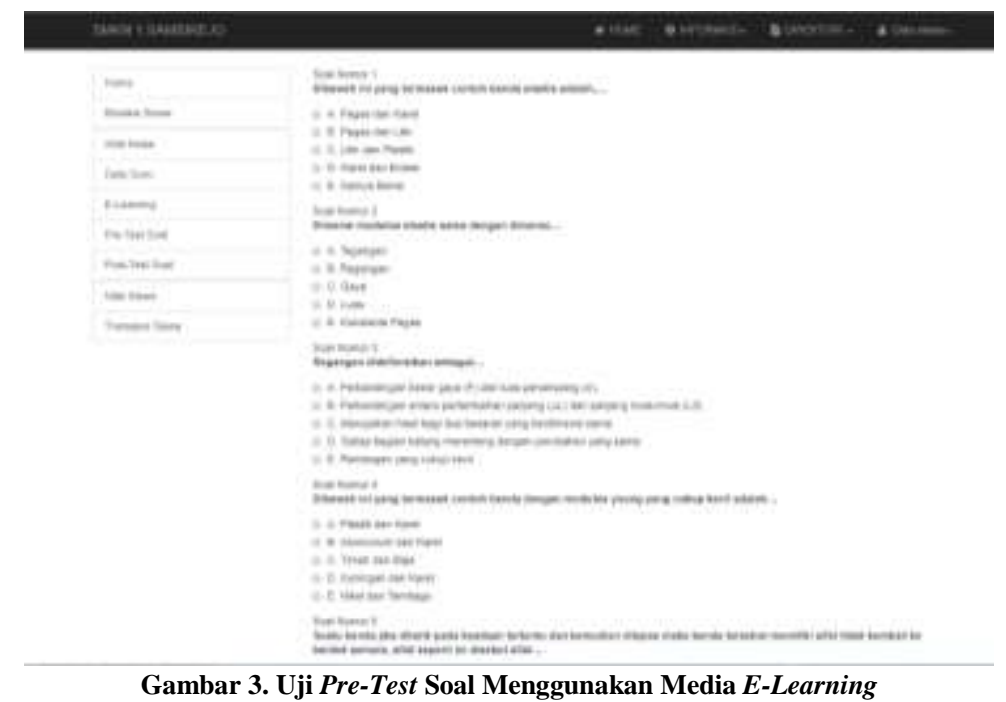

Pada siklus II siswa dibimbing untuk lebih aktif dalam pembelajaran menggunakan media E-Learning. Proses pembelajaran pada tahap siklus II tidak jauh beda dengan siklus I. Materi pembelajaran pada siklus II ini yaitu Hukum Hooke dan aplikasinya dalam kehidupan sehari-hari sehingga siswa mampu memahami dan mengaplikasikan pada lingkungan di sekitarnya. Pada siklus II siswa mengerjakan soal post-test pada media 
pembelajaran E-Learning, yang nantinya akan digunakan sebagai pengukur prestasi belajar siswa. Berikut tampilan soal post-test menggunakan media pembelajaran $E$ Learning.

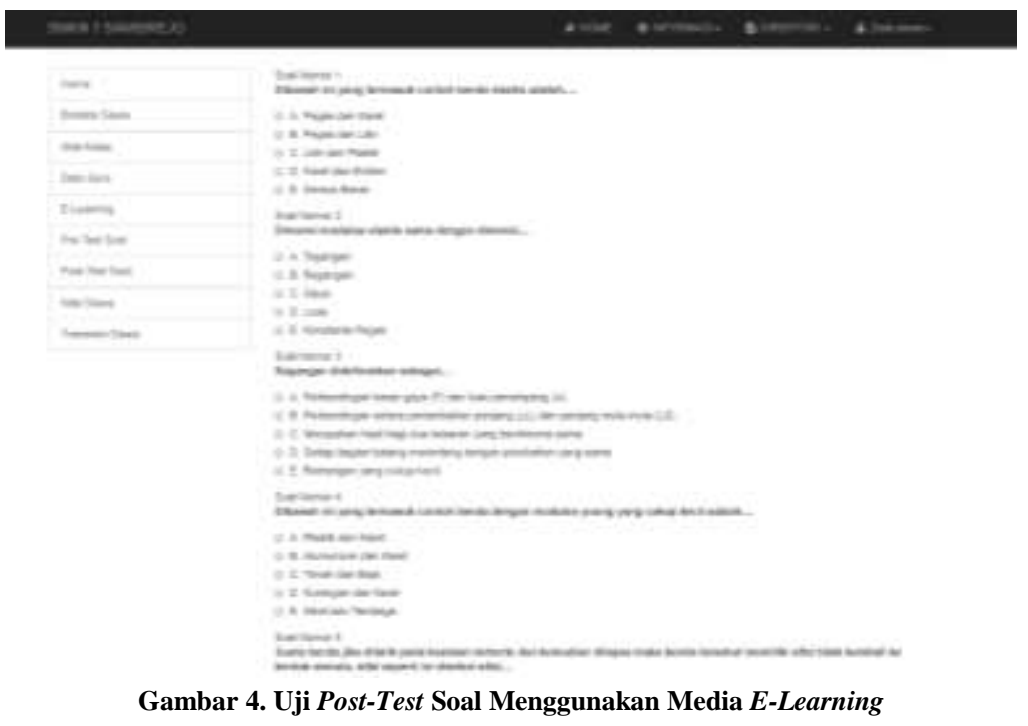

\section{2) Prestasi Belajar}

Pada siklus I secara garis besar kegiatan belajar menggunakan metode Penelitian Tindakan Kelas (PTK) sudah dilaksanakam dengan baik, walaupun peran guru masih cukup dominan untuk memberikan penjelasan dan arahan, karena pembelajaran menggunakan E-Learning masih baru dirasakan oleh siswa. Pada akhir proses belajar mengajar siswa diberi tes berupa pre-test dengan tujuan untuk mengetahui tingkat keberhasilan siswa dalam proses belajar mengajar yang telah dilakukan. Dalam tahapan ini siklus I belum bisa dikatakan meningkatan prestasi belajar siswa karena belum adanya peningkatan prestasi belajar. Maka dari itu dilakukan tahap siklus II. Dalam siklus II kegiatan pembelajaran sama dengan siklus 1, siswa didorong untuk lebih aktif dan terampil dalam menjalankan media E-Learning serta lebih teliti dalam mengerjakan soal post-test yang sudah disediakan di dalam media E-Learning. Berikut hasil peningkatan prestasi belajar siswa untuk siklus 1 dan II.

Tabel 1. Perbandingan Nilai Hasil Siklus 1 dan Siklus II

\begin{tabular}{lcccc}
\hline Uraian & Target & Siklus I & Siklus II & Peningkatan \\
\hline Skor rata-rata & 70 & 43,00 & 72,56 & 29,56 \\
\hline $\begin{array}{l}\text { Jumlah siswa yang } \\
\text { tuntas }\end{array}$ & - & - & 22 & - \\
\hline $\begin{array}{l}\text { Jumlah siswa yang } \\
\text { tidak tuntas }\end{array}$ & - & 32 & 10 & 22 \\
\hline
\end{tabular}

Keterangan : KKM 70

Berikut disajikan diagram yang menunjukkan nilai rata-rata Siklus I dan Siklus II hasiL perbandingan sebagai bukti peningkatan prestasi belajar siswa. 


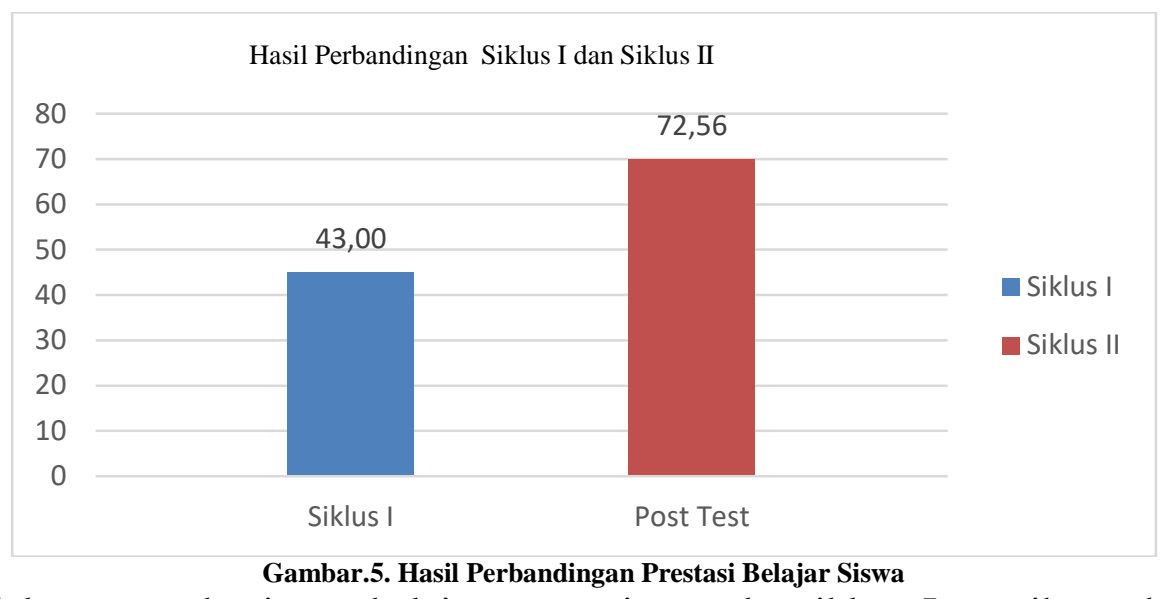

Pada pelakasanaan kegiatan belajar mengajar pada siklus I masih terdapat banyak kekurangan, sehingga perlu adanya revisi untuk dilakukan pada siklus berikutnya. Guru perlu lebih terampil dalam memotivasi siswa dan lebih jelas dalam menyampaikan tujuan pembelajaran. Dimana siswa diajak untuk terlibat langsung dalam setiap kegiatan yang akan dilakukan. Guru menugaskan siswa untuk membaca materi ajar di rumah sebelum dipelajari di sekolah. Pada siklus II selama proses belajar mengajar guru telah melaksanakan semua pembelajaran dengan baik. Meskipun ada beberapa aspek yang belum sempurna, tetapi presentase pelaksanaannya dalam peningkatan prestasi belajar siswa cukup besar. Berdasarkan data hasil pengamatan diketahui bahwa siswa aktif selama proses belajar mengajar berlangsung. Kekurangan pada siklus I sebelumnya sudah mengalami perbaikan dan peningkatan sehingga menjadi lebih baik. Hasil prestasi belajar siswa pada siklus II mencapai ketuntasan.

Tabel 2. Effect Size Media Pembelajaran E-Learning

\begin{tabular}{|c|c|c|c|c|}
\hline \multicolumn{2}{|c|}{ Nilai Rerata } & \multirow[t]{2}{*}{ Cohen'sd } & \multirow[t]{2}{*}{ Effect Size $(r)$} & \multirow[t]{2}{*}{ Kriteria } \\
\hline Siklus I & Siklus II & & & \\
\hline 54 & 76 & 3.111 & 0.841 & Besar \\
\hline
\end{tabular}

Berdasarkan data Effec Size diatas memiliki nilai Cohen's $d$ sebesar 54 pada nilai siklus I dan nilai siklus II sebesar 76 sehingga nilai Cohen's $d$ yang diperoleh nilai sebesar 3,111 yang digunakan untuk menghitung $r$ sehingga $r$ diperoleh 0,841 , hal tersebut menunjukkan bahwa pembelajaran menggunakan media E-Learning memiliki pengaruh yang besar terhadap peserta didik dalam kriteria $0,8 \leq r \leq 2,0$ dan dalam hal ini DI siklus II hanya berjumlah 10 siswa saja sehingga peneliti mudah dalam mengarahkan murid untuk menjalankan media E-Learning pada kondisi kelas selama pembelajaran berlangsung.

\subsection{Pembahasan}

Berdasarkan data pada siklus I , menghasilkan nilai skor rata-rata sebesar 43,00 dengan batas tuntas KKM dengan nilai 70. Pada penilaian siklus I jumlah siswa yang tidak tuntas 32 orang siswa dan jumlah siswa yang tuntas 0 orang, dalam hal ini dikerenakan masih kurangnya pemahaman siswa dalam menjalankan media E-Learning yang dijalankan setiap masing-masing siswa sehingga perlu adanya penjelasan kembali mengenai media E-Learning yang disajikan. Pada hal ini tentu saja menjadi motivasi guru untuk lebih memotivasi peserta didik supaya fokus terhadap pembelajaran media E-Learning yang dijalankan selama proses 
pembelajaran berlangsung. Pada tahap siklus I guru juga belum mampu mengkondisikan suasana kelas dengan tenang, masih banyak siswa yang bingung dalam menjalankan media E-Learning, namun pada akhirnya setiap siswa mampu menjalankan media tersebut. Hal ini menjadi fokus utama guru untuk lebih mengkondisikan suasana pada saat pembelajaran berlangsung.

Pada siklus II, menghasilkan nilai skor rata-rata sebesar 72,56 dengan batas tuntas KKM dengan nilai 70. Pada penilaian siklus II jumlah siswa yang tidak tuntas sebesar 10 orang siswa dan jumlah siswa yang tuntas sebanyak 22 orang. Dalam hal ini berarti terjadi peningkatan prestasi belajar siswa sebanyak 29,56. Dengan ini maka pengguanaan media pembelajaran menggunakan E-Learning berbasis web dapat meningkatkan prestasi belajar siswa. Dalam hal ini guru juga masih banyak kekurangannya dalam menyampaikan materi, dikarenakan ada siswa yang masih belum paham akan konsep dasar elastisitas dan hukum hooke. Sebagaian kecil siswa juga belum paham cara membagikan hasil video pembelajaran yang telah mereka pelajari untuk dibagikan ke media lain, hal ini terbatas dengan sinyal jaringan internet yang lambat. Tetapi pada siklus II sebagian besar siswa sudah mampu menjalankan media E-Learning dengan tepat hanya saja pada waktu mengerjakan uji tes banyak yang kekurangan waktu sehingga ada beberapa siswa yang belum selesai dalam mengejerkan soal tersebut.

Media pembelajaran E-Learning berbasis web ini menampilkan berbagai macam refrensi video pembelajaran aplikasi fisika dalam kehidupan sehari-hari yang disesuaikan dengan kebutuhan penggunanya. Sehingga pada tahap sikluas 1 dan siklus II terlihat perbedaan yang mencolok didalamnya dikarenakan media ini masih program awal di dalam lingkungan sekolah SMK N 1 Sambirejo. Media ini diharapkan kedepannya mampu membantu proses belajar mengajar para guru terutama di SMK N 1 Sambirejo.

Effect size atau ukuran dampak digunakan untuk mengetahui besar pengaruh media pembelajaran yang digunakan juga metode yang diterapkan untuk siswa. Pada penelitian ini effect size digunakan untuk mengetahui besar pengaruh dari siklus I dan siklus II yang menggunakan media pembelajaran E-Learning terhadap peningkatan prestasi belajar siswa. Dalam hal ini effect size memperoleh hasil yang besar dampaknya bagi kegiatan belajar mengajar siswa dengan perolehan nilai sebesar 0,841 dengan kategori "besar".

Dari hasil peningkatan perbandingan nilai pada siklus I dan siklus II juga hasil effect size masih banyak kekurangan dalam penyampaian materi maupun sosialisasi mengenai media pembelajaran yang baru diterapkan oleh siswa kelas X di SMK N 1 Sambirejo sehingga guru lebih banyak mengkoreksi diri dalam penyampaiannya dalam kegiatan belajar mengajar.

\section{Kesimpulan}

Implementasi media pembelajaran E-Learning ini dapat menjadi perhatian lebih untuk dikembangkan lagi kedepannya sehingga semua warga sekolah di SMK lebih optimal dalam menggunakan disemua kegiatan belajar mengajar sehingga siswa lebih tertarik dan lebih banyak wawasan dari media luar.

Media pembelajaran E-Learning berbasis web ini mampu meningkatkan prestasi belajar siswa kelas X SMK N 1 Sambirejo terutama dalam mata pelajaran fisika yang banyak aplikasinya dalam kehidupan sehari-hari sehingga siswa mampu untuk menciptakan ide kreatif lagi mengenai materi-materi yang ada di dalam fisika. Denga adanya pencetusan awal ini diharapkan adanya masukkan mengenai kekurangan dan kelebihan media E-Learning berbasis web. 
Hasil perbandingan pada siklus I dan siklus II menunjukkan yaitu siklus I diperoleh nilai 43,00 dengan batas KKM dengan nilai 70. Pada siklus I jumlah siswa yang tidak tuntas berjumlah 32 orang siswa hal ini dikarenakan skor masing-masing siswa masih dibawah KKM yaitu 70, sedangkan jumlah siswa yang tuntas berjumlah 0 orang siswa. Pada siklus II diperoleh nilai 72,56 dengan batasan KKM dengan nilai 70. Pada siklus II jumlah siswa yang tuntas berjumlah 22 orang siswa, sedangkan untuk siswa yang tidak tuntas berjumlah 10 orang siswa. Hal ini tentu saja mendapatkan peningkatan prestasi belajar yang sudah maksimal. Hasil peningkatan diperoleh sebesar nilai 29,56.

Dari data diatas bisa diambil kesimpulan bahwa implementasi media pembelajaran ini mampu mendorong motivasi dan kreatifitas siswa dalam bidang Teknlogi dan Informatika terutama dalam ham pembelajaran Fisika dan Aplikasinya. Diharapkan kedepannya sekolahsekolah yang lain pun ikut berperan aktif lagi untuk memajukan pendidikan di Indonesia.

\section{Saran}

1) Implementasi media pembelajaran E-Learning ini mampu meningkatkan prestasi belajar siswa meskipun harus mengalami proses terlebih dahulu supaya siswa memahami fungsi dan keguanaan media pembelajaran E-Learning berbasis web tersebut. Media ini layak untuk digunakan dalam proses pembelajaran dan dikembangkan lebih lanjut sehingga siswa maupun guru dapat menggunakan secara maksimal.

2) E-Learning merupakan salah satu alternatif media pembelajaran interaktifyang mengembangkan sikap aktif, mandiri dan kreatif, maka sebaiknya mediapembelajaran ini dapat digunakan untuk setiap materi TIK maupun mata pelajaran yang lain. Persiapan format penilaian keaktifan siswa juga sangatditekankan demi menghasilkan data yang lengkap.

3) Sebelum pelaksanaan pembelajaran menggunakan media ini, guru harus dapatmempersiapkan komponen pendukung, seperti rencana pembelajaran yang lebih sistematis agar lancar serta jelas apa yang akan dilakukan, kemudianmateri serta tugas di dalam E-Learning harus sudah disediakan sebelumpembelajaran dimulai.

4) Media pembelajaran E-Learning membutuhkan waktu ekstra dalam persiapan,sehingga sebelum memulai pembelajaran sebaiknya guru telahmempersiapkannya dengan sangat matang. Karena media ini digunakan olehguru sepanjang pembelajaran.

5) Pengkondisian belajar siswa ketika pembelajaran E-Learning berlangsungharus lebih diperhatikan karena siswa akan dituntut secara mandiri menggali materi yang diajarkan secara lebih mendalam, sekaligus mengembangkanpengetahuan seluas mungkin.

6) Untuk penelitian lebih lanjut, sebaiknya melakukan pengembangan sejenistetapi dengan pokok bahasan yang berbeda, supaya dapat dilihat bahwapenerapan media pembelajaran E-Learning ini sangat sesuai untuk diterapkanpada materi apapun yang menuntut keterampilan praktek siswa.

\section{Daftar Pustaka}

Arsyad, A. (2007). Media Pembelajaran. Jakarta: Rajagrafindo Persada.

Arifin, Z. (2008). Evaluasi Pembelajaran. Bandung: PT Remaja Rosdakarya.

Ayre, C., \& Scally, A. J. (2013). Critical Values for Lawshe's Content Validity Ratio: Revisting the Original Methode Of Calculating. Methods Plainly Speaking, Vol 47 (1), 79-86.

Darmawan, D. (2014). Pengembangan E-Learning Teori Dan Desain. Bandung: PT Remaja Rodakarya. 
Dunne, E. a. (1996). Education. New York: Taylor \& Francis e-Library.

Hamalik, O. (2008). Perencanaan Pengajaran Berdasarkan Pendakatan Sistem. Jakarta: Bumi Aksara.

Harton, W. H. (2003). E-Learning Tools and Technologies: A consumer guide for trainers, teachers, educators, and instructional designers. USA: Wiley Publishing, Inc.

Koran, J. K. (2002). Aplikasi 'E-Learning' Dalam Pengajaran Dan Pembelajaran Di Sekolah-Sekolah Malaysia: Cadangan Perlaksanaan Pada Senario Masa Kini, Pasukan Projek Rintis Sekolah Bestari Bahagian Teknologi Pendidikan . Malaysia: Kementrian Pendidikan Malaysia.

Mudlofir, A. (2015). Desain Pembelajaran Inovatif. Jakarta: Rajagrafindo Persada

Popham, W. J. (2003). Test Better, Teach Better: The Instructional Role of Assessment. Jakarta: Rineka Cipta.

Purwanto. (2011). Evaluasi Hasil Belajar (p. 50). Yogyakarta: Pustaka Belajar.

Renstra, K. (2015). Rencana Strategis Sekretariat Jenderal 2015-2019. Jakarta: Kementrian Pendidikan dan Kebudayaan Indonesia.

Risnawati, I., Kaniawati, I., \& Efendi, R. (2013). Efektivitas Penerapan Model Pembelajaran Inkuiri Berbasia Fisika Outdor Dengan Menggunakan Modul Kontekstual Untuk Meningkatkan Keterampilan Proses Sains Siswa Pada Materi Fluida Dinamis. Jurnal Wahana Pendidikan Fisika 1, 66-75.

Rosenberg, M. J. (2001). E-Learning: Strategies for Delivering Knowledge in the Digital Age. United State: The McGraw-Hill.

Rusman, Kurniawan, D., \& Riyana, C. (2012). Pembelajaran Berbasis Teknologi Informasi dan Komunikasi. Jakarta: Rajagrafindo Persada.

Rudyanto, A.M. (2011). Pemrograman Web Dinamis Menggunakan PHP dan MySQL. Yogyakarta: PT Andi Perkasa.

Sobry, S. (2008:87). Belajar dan Pembelajaran. In Rusman, D. Kurniawan, \& C. Riyana, Pembelajaran Berbasis Teknologi Informasi dan Komunikasi (p. 87). Bandung: Prospect.

Suparwoto. (2015). Laporan Tahunan 2014. Jakarta: Kementrian Komunikasi dan Informatika.

Trianto.(2015). Model Pembelajaran Terpadu. Jakarta: Bumi Aksara 